\title{
Uma etnografia das Varas Especiais da Infância e da Juventude
}

\author{
PAUla Miraglia
}

\section{RESUMO}

Este artigo propõe uma abordagem etnográfica das audiências com crianças e adolescentes realizadas nas Varas Especiais da Infância e da Juventude em São Paulo. Além do estudo de caso, o artigo discute as vicissitudes da relação entre o jovem e a justiça no Brasil, analisa as dificuldades de implementação do Estatuto da Criança e do Adolescente e apresenta reflexões sobre as especificidades de uma etnografia quando o direito é o objeto.

PALAVRAS-CHAVE: Estatuto da Criança e doAdolescente; justiça, Febem.

\section{SUMMARY}

This article proposes an ethnographical approach to the audiences with children and adolescents held in "Juvenile Courts" in São Paulo. It discusses problems involving the Brazilian legislation for children, analyses the difficulties of implementation of the Statute for the Child and the Adolescent and reflects about the particularities of working with ethnography when the Law is the object.

KEYWORDS: Statute for the Child and the Adolescent; Justice; Febem.

Nenhuma sociedade é perfeita. Por natureza, todas comportam uma impureza incompativel com as normas que proclamam, e que se traduz de modo concreto numa certa dose de injustiça, de insensibilidade, de crueldade. Como avaliar essa dose? A pesquisa etnográfica consegue.

(Lévi-Strauss, em Tristes Trópicos)

[1] Este artigo é uma adaptação de um capítulo da minha dissertação de mestrado, "Rituais da Violência - a Febem como espaço do Medo em São Paulo", defendida no departamento de Antropologia Social da Universidade de São Paulo, em abril de 2002. A despeito da distância
No bairro do Brás, na cidade de São Paulo, funcionam algumas das "Varas Especiais da Infância e da Juventude" (VEIJ). Para lá, são encaminhados jovens com menos de 18 anos que cometem o que o Estatuto da Criança e do Adolescente (ECA) chama de "ato infracional". Por ato infracional, entende-se "a conduta descrita como crime ou contravenção penal” (ECA, cap. 1, art. 103). 
As VEIJ abrigam as audiências para apurar a culpabilidade ou não do jovem e então decidir qual medida sócio-educativa lhe deve ser aplicada. Tais audiências são palcos privilegiados de disputas políticas que apresentam atores já tradicionais no cenário dos conflitos envolvendo direitos da infância e da adolescência. Configuram-se como momento singular, onde temos reunidos, numa mesma cena, representantes da sociedade e do Estado - juízes, promotores e procuradores -, os próprios jovens e, em alguns casos, suas famílias.

Aproveitando o crédito dado por Lévi-Strauss à pesquisa etnográfica, na citação que abre este ensaio, pretendemos, a partir de uma etnografia dessas audiências, mostrar como o Poder Judiciário tem um papel fundamental na constituição da identidade de "menor infrator". Ainda que utilizando instrumentos legítimos como o Estatuto da Criança e do Adolescente, muitas vezes o Judiciário o faz de maneira enviesada. Uma análise mais atenta das audiências mostra como as relações estabelecidas nessa etapa do processo são marcadas pela assimetria entre os atores, pela reafirmação constante das hierarquias, por uma grande disputa e abuso de poder. $\mathrm{O}$ resultado mais evidente, em grande parte dos casos, é a condução de audiências de forma pouco convencional.

A análise ora apresentada é fruto da observação de "audiências de conhecimento", isto é, audiências realizadas para apurar a culpabilidade ou não do acusado. Sessões dessa natureza, pautadas por um conjunto de regras e normas cujo objetivo formal é a aplicação da lei, são o espaço oficial para a resolução de conflitos. Em outras palavras, numa audiência de conhecimento, o juiz apura, após a leitura do processo - na presença de um promotor público, um procurador da Procuradoria de Assistência Judiciária gratuita, ou de um advogado constituído, do próprio jovem acusado e em alguns casos seus pais ou algum parente próximo - , se esse jovem cometeu ou não um ato infracional. Se a culpa for verificada, o juiz aplica uma medida sócioeducativa prevista pelo ECA.

Esse espaço, contudo, mostrou-se um campo rico em teatralidade e dramaticidade, onde além da ação legal do Estado, representado aqui pelo Poder Judiciário, nos deparamos com todo um sistema simbólico específico que estabelece diálogos muito particulares com as noções de menoridade, punição, culpabilidade e a própria idéia de Estado.

Essa percepção sugere, em primeiro lugar, que a pesquisa etnográfica pode contribuir para ampliar a compreensão dos mecanismos de funcionamento das "Varas Especiais da Infância e da Juventude", colocando em perspectiva a tarefa primordial que seria a aplicação da lei e a resolução de conflitos, para iluminar aspectos que envolvem disputas de poder, posições políticas e afirmação de valores. Nesse sentido, abandonamos aqui a idéia de que um tribunal seria um espaço neutro para a resolução de conflitos, nos opondo ao que Bourdieu identificou como "a representação nativa que descreve o tribunal como entre a dissertação e a publicação deste artigo, posso afirmar que o panorama das Varas Especiais da Infância e da Juventude mudou muito pouco desde então. Por conta do tamanho e formato deste texto, foram suprimidas discussões importantes sobre a legislação mundial para a infância e juventude, sobre o Estatuto da Criança e do Adolescente, bem como reflexões sobre as especificidades de uma etnografia quando o direito é o objeto. 
[2] Bourdieu, Pierre. O poder simbólico. Lisboa, Difel, 1989, p.228.

[3] Geertz, Cliford. O saber local. $3^{\text {a }}$ ed., Petrópolis, Editora Vozes, 2000, p.170. um espaço separado e delimitado em que o conflito se converte em diálogo de peritos e o processo, como um progresso ordenado com vista à verdade." 2 Propomos uma interpretação das cenas apresentadas em cada audiência como uma tentativa de lê-las na sua chave mais dramática: voltar o olhar para as tensões e intenções, os valores em jogo $e$ as disputas de poder que nos chamam a ver, também nos termos de Bourdieu, o efeito simbólico do ato jurídico.

\section{DA ANTROPOLOGIA E dO DIREITO (OU COMO dOMESTICAR SEU PENSAMENTO)}

Lançar mão da antropologia, não só dos seus métodos de pesquisa, mas também de seu arsenal teórico, para analisar o discurso do direito e de seu campo de atuação é, na verdade, promover o encontro entre duas disciplinas que se colocam em lados opostos no que se refere à dimensão simbólica do poder. Podemos dizer que o direito opera na chave da "razão prática". Numa lógica de causa e efeito, a aplicação da lei baseiase numa correspondência direta entre dado, fato, prova e a imagem de justiça. Para a antropologia, contudo, a idéia de "realidade dos fatos", pura e simplesmente não cabe, ou pelo menos não vem a ser uma preocupação exclusiva. Como aponta Clifford Geertz, há uma espécie de preconceito advindo da idéia de que "o 'simbólico' se opõe ao 'real' como o extravagante ao sóbrio, o figurativo ao literal, o obscuro ao simples, o decorativo ao substancial". Ainda nas palavras do autor, a dramaturgia do poder não é exterior ao seu funcionamento. O real, segundo ele, é tão imaginado como o imaginário. ${ }^{3}$ Para falar do poder, a antropologia busca elementos que constroem sua simbologia dramática.

A despeito da diferença de idade entre as duas, não é de hoje que a antropologia e o direito têm encontrado espaços comuns de debate. Esses encontros, contudo, têm se dado de maneiras muito diferentes. Nesse sentido, propomos uma pequena reflexão acerca da trajetória das aproximações e estranhamentos entre as duas disciplinas.

\footnotetext{
[4] Definem-se como juristas "as pessoas versadas nas ciências jurídicas, como o professor de direito, $o$ jurisconsulto, o juiz, o membro do Ministério Público, o advogado". Cintra, Antonio Carlos de Araújo, Grinover, Ada Pellegrini \& Dinamarco, Cândido Rangel. Teoria geral do processo. $16^{\mathrm{a}}$ ed., São Paulo, Editora Melhoramentos, 2000, p. 219. Como em todas as profissões, diferentes profissionais relacionam-se de maneiras diversas com o direito, alguns se dedicando mais à sua aplicação prática, enquanto outros a reflexões mais filosóficas sobre a disciplina.
}

Para os juristas ${ }^{4}$, há uma relação imediata entre direito e sociedade. $\mathrm{Na}$ verdade, mais do que isso, não há sociedade sem direito. Pois, para que o homem "viva em sociedade", é imprescindível que os diversos interesses manifestos na vida social, bem como os conflitos advindos desses interesses, sejam orquestrados e resolvidos. Logo, o direito teria primordialmente a função de ordenação social, sendo o Estado o meio para garantir essa ordenação. A existência do Leviatã assegura, pela violência ou, mais especificamente, pelo monopólio dela, que os homens não vivam na condição de "guerra de todos contra todos".

Isso posto, poderíamos, de forma generalizante, assumir as premissas de que sob a ótica jurídica não há sociedade sem Estado e de 
que o direito, na sua forma de cultura legal, por conseqüência, é um valor universal. Ainda que explorássemos as nuanças dos debates mais recentes sobre a universalidade do direito e dos modos de organização social sob essa perspectiva, tentando com isso relativizar a posição das ciências jurídicas, é certo que do ponto de vista formal da disciplina poderíamos confirmar essas duas premissas ${ }^{5}$. Não se trata de dizer que há por parte do direito uma preocupação em universalizar o modelo, estendendo-o a sociedades que não a ocidental. Mas sim apontar uma perspectiva de certa maneira ainda evolucionista e exclusiva por parte da disciplina, uma vez que esta não "dá conta" de sociedades que não têm uma organização social baseada num modelo que compreenda a figura do Estado.

Desse modo, não precisamos ir muito longe para perceber por que o ideário do direito despertaria o interesse da antropologia. Se o primeiro parte de um modelo universal para pensar a organização social, a segunda percorre o trajeto inverso ao encontrar nesses modelos particularidades que põem em xeque a sua própria generalização.

Se, para o advogado, a lei interessa na medida em que separa o certo do errado, o lícito do ilícito, para o antropólogo a lei ou a legislação representam apenas o aspecto formal do controle social, mais uma manifestação desse conjunto de valores que poderíamos chamar de "cultura" (ainda que a definição desse termo seja um desafio constituinte para a antropologia). Não se trata aqui de menosprezar a importância da lei, mas apenas apontar que a ela somam-se outros mecanismos de efetivação de autoridade e imposição da regra. Em outras palavras, podemos dizer que o controle se dá pela via legal, mas também por uma série de outros reguladores sociais que atuam em esferas de poder alternativas àquelas gerenciadas pelo Estado, ligados, por exemplo, a noções como valor, tradição, hierarquia, legitimidade e obediência.

O interesse da antropologia pelo universo das leis e sua aplicação na resolução de conflitos não é recente. Junto com os subcampos da disciplina que aparecem após a Segunda Guerra Mundial — como, por exemplo, a antropologia política e a antropologia da religião -, está a antropologia do direito. ${ }^{6}$ Assim como para o restante da disciplina, os primeiros objetos de estudo da antropologia jurídica foram as sociedades tradicionais ou ditas primitivas. As publicações de Crime and custom in sauvage society, de Bronislaw Malinowski, em 1926, e posteriormente de The Cheyenne Way: conflict and law in a primitive jurisprudence, de Llewellyn \& Hoebel, em 1941, marcam o início dos chamados estudos de antropologia jurídica ${ }^{7}$ para as escolas britânica e americana, respectivamente. De maneira geral, nesses estudos, encontramos uma análise das normas legais que regem as sociedades e de como são aplicadas na resolução de conflitos ou disputas. Ao estudar as chamadas sociedades sem Estado - sem instituições formais como o Poder Judiciário, na maioria das vezes de tradição oral, onde as leis não estão documentadas -, o antropólogo se vê obrigado a identificá-
[5] Os livros utilizados atualmente nos cursos de direito são, talvez, a melhor ilustração. Segundo Cintra, Grinover e Dinamarco, "nas fases primitivas da civilização dos povos, inexistia um Estado suficientemente forte para superar os ímpetos individualistas dos homens e impor o direito acima da vontade dos particulares: por isso, não inexistia um órgão estatal que, com soberania $e$ autoridade, garantisse o cumprimento do direito, como não havia sequer as leis (normas gerais e abstratas impostas pelo Estado aos particulares). Assim, quem pretendesse alguma coisa que outrem o impedisse de obter haveria de, com sua própria força e na medida dela, tratar de conseguir por si mesmo a satisfação de sua pretensão. [...] A esse regime chama-se autotutela (ou autodefesa) e hoje, encarando-a do ponto de vista da cultura do século $\mathrm{xx}$, é fácil ver como era precária e aleatória, pois não garantia a justiça, mas a vitória do mais forte, mais astuto ou mais ousado sobre o mais fraco ou mais tímido." (Op. cit., p.21).

[6] Nader, Laura (ed.). Law in culture and society. $1^{\text {a }}$ ed. [1969], Berkeley/ Los Angeles, University of California Press, 1997.

[7] Gulliver cita, entre outras, as monografias de Barton (1919), Ifugao Law, Rattray (1929), Ashanti Law and Constitution e Hogbin (1934), Law and Order in Polynesia. (Gulliver, P. H. "Case studies of Law in non-Western societies: introduction". In: Nader, Laura (ed.). Law in culture and society. $1^{\mathrm{a}}$ ed. [1969], Berkeley/Los Angeles, University of California Press, 1997). 
[8] Idem, p. 13.

[9] Shirley, Robert Weaver. Antropologia jurídica. São Paulo, Editora Saraiva, 1987.

[10] Geertz, Clifford, op. cit, p.13.

[11] Bourdieu, Pierre, op. cit., p.211. las "em ação": seria na mediação e resolução de conflitos que os mecanismos de contenção e de ordenação social se revelariam. Por isso, no caso específico da antropologia jurídica, o foco principal é o " estudo de processos, e em particular os processos de acordo de disputas" ${ }^{\text {. }}$.

A idéia de observar a lei em ação sublinha o valor da pesquisa etnográfica na promoção de uma análise antropológica de um fato jurídico. É como se precisássemos assistir à aplicação da lei para interpretar seu funcionamento. Logo, se os juristas naturalizam o direito, o trabalho do antropólogo é mostrá-lo como uma construção pautada e orientada por um conjunto específico de valores: o direito seria mais canal de compreensão de uma determinada cultura ou de um aspecto cultural específico. Para tanto, coloca em xeque tais valores que se apresentam sob a forma de leis, desvendando a simbologia de poder manifesta nas relações entre partes conflitantes. Para os advogados, há, na dinâmica dos processos judiciais, espaço para a "interpretação da lei". A antropologia sugere que a ação de interpretar deve ser ampliada; tal perspectiva nos propõe uma reflexão sobre a interpretação das ações jurídicas, dos seus discursos, sobre as variações na aplicação da lei e, no limite, sobre a própria idéia de justiça.

Formalmente, a atuação da pesquisa antropológica no campo do direito pode ser classificada em três categorias: a chamada "antropologia legal", o campo de atuação mais antigo e tradicional da antropologia no direito, que compreenderia os estudos do direito em sociedades simples. Os trabalhos citados acima poderiam ser classificados de tal maneira. A definição "antropologia jurídica" refere-se aos estudos que fazem uso das técnicas de pesquisa da antropologia e seu repertório teórico para estudar as instituições do Poder Judiciário e do universo do direito como a polícia, as prisões ou as cortes. Finalmente, o "direito comparado" constitui também um campo de atuação para o antropólogo, na medida em que exige justamente o exercício do relativismo cultural próprio da disciplina?.

Partindo dessa definição, poderíamos tomar a análise aqui proposta como um trabalho de antropologia jurídica. Entretanto, interessam menos os limites que tal rótulo pode colocar e mais as possibilidades que se abrem quando interpretamos o discurso jurídico que se apresenta nas audiências. Na verdade, nos valemos do que Clifford Geertz chama de "saber local", isto é, uma tentativa de explicar fenômenos sociais "colocando-os em estruturas locais de saber" ${ }^{\circ}$, ou do que Pierre Bourdieu chama de "sistema simbólico particular", para então apreender "o universo social especifico (no qual o direito) se produz e se exerce"

\section{A CRIANÇA E A LEI, O deSENVOLVIMENTO dA LEgISLAÇÃo}

O Brasil conta hoje com o Estatuto da Criança e do Adolescente (ECA), instrumento legal criado pela Constituição Federal brasileira de 1988, Lei 8.069, em vigor desde 13 de julho de 1990. A criação dessa lei 
veio determinar tratamento específico às crianças (até 12 anos de idade) e adolescentes (até 18 anos de idade) e teve grande impacto nas políticas de atendimento ao jovem, no tratamento que este passou a receber da justiça e nas garantias dos seus direitos fundamentais. Não devemos, no entanto, ter a percepção da criação do ECA como um movimento brasileiro isolado, e sim como parte de um processo mundial de consolidação dos direitos dos jovens. A revisão da legislação brasileira está diretamente ligada a um movimento mundial de atenção, ampliação e valorização dos direitos infantis, pautados por uma nova concepção de direito e cidadania, que tem seu desenrolar ao longo do século XX, vinculado a uma nova percepção da criança como ser humano em fase de desenvolvimento, com particularidades, necessidades especiais e que conseqüentemente deve ter direitos especiais, que vão ao encontro das necessidades dessa fase de desenvolvimento. Nesse contexto, a criança e o adolescente adquirem status de cidadãos plenos, com direitos que devem ser respeitados e protegidos, e passam a ser encarados como prioridade absoluta da sociedade política e civilmente organizada.

Como aponta Marques, há um consenso entre os autores que tratam do tema sobre a caracterização da Constituição Federal de 1988, e do ECA em 1990, como marcos históricos na criação de uma nova idéia de cidadania de crianças e adolescentes ${ }^{12}$.

A criação e decreto do estatuto acarreta não só uma série de mudanças na prática da lei, mas supostamente também na relação de responsabilidade entre crianças e jovens, Estado e sociedade civil. O ECA apresenta uma nova forma de tratamento e de nomeação. Numa tentativa de desfazer estereótipos criados a partir da associação entre menor, crime e delinqüência, fala-se agora em ato infracional em vez de crime, adolescente ou pessoa em desenvolvimento em contraposição à expressão menor ou delinqüente juvenil. A mudança na conceituação e essa conotação transitória que a infração adquire revelam também a perspectiva de ressocialização presente na nova lei. Esta sempre foi uma aposta do ECA.

O estatuto propõe, além disso, uma reestruturação dos instrumentos de justiça, estabelecendo a criação de "Varas Especiais da Infância e da Juventude", em oposição à justiça comum. Os menores de 18 anos, além de inimputáveis penalmente, devem agora ser julgados de acordo com as infrações previstas no Código Penal, mas num fórum de justiça especial.

Uma vez constatada a infração, o juiz pode aplicar ao adolescente alguma das seguintes medidas sócio-educativas: advertência; obrigação de reparar o dano; prestação de serviços à comunidade; liberdade assistida; inserção; regime de semiliberdade; internação em estabelecimento educacional ${ }^{13}$.

Foi estabelecido pelo ECA que deve haver uma correspondência entre a medida aplicada e a gravidade do ato infracional cometido.
[12] A autora faz ainda uma rica revisão bibliográfica sobre o assunto.

[13] As três primeiras medidas são determinadas no caso de infrações pouco graves. Já a liberdade assistida (LA) implica o comparecimento do jovem nessa condição a um posto de assistência social, determinado pelo juiz, pelo menos uma vez por mês, por um período mínimo de seis meses. O regime de semiliberdade é uma "meia internação": o juiz determina a internação numa instituição educacional, mas esse interno tem liberdade para, durante o dia, estar fora da instituição (estudando ou trabalhando preferencialmente), tendo a obrigação de retornar e passar a noite na instituição. A internação, por sua vez, acarreta a supressão da liberdade e deve ser aplicada como último recurso; como resposta a atos infracionais graves. Mesmo nesse caso, só é permitida para adolescentes (de 12 a 18 anos) e nunca para crianças com menos de 12 anos. 
[14] É fundamental ressaltar que a internação aparece como a última opção e "[...] constitui medida privativa da liberdade, sujeita aos princípios de brevidade, excepcionalidade e respeito à condição peculiar de pessoa em desenvolvimento" (ECA, art. 121). O que significa que ela deveria ser o último recurso utilizado no julgamento de menores de 18 anos. O número de internações e a eficácia desta medida em seu caráter sócio-educativo são talvez alguns dos maiores motivos de conflitos entre o Ministério Público e a PAJ.
Além do quê, devem-se priorizar medidas que possam ser cumpridas em meio aberto, isto é, que não impliquem a internação e a privação da liberdade ${ }^{14}$.

Vamos nos deter aqui em dois aspectos sociais que considero marcas fortes do estatuto e que são "bons para pensar" o sistema de justiça: o primeiro é a substituição do caráter punitivo das medidas por uma postura sócio-educativa. Vimos que a maior parte das medidas previstas no ECA não se configura como supressão da liberdade. Mesmo a internação é pensada como uma medida sócio-educativa, pois traduz a intenção do Estado em se responsabilizar pelo adolescente. O segundo é a consolidação da idéia da criança como "sujeito de direitos em condição peculiar de desenvolvimento", em contraposição à idéia de adolescentes em situação irregular, possíveis objetos de tutela do Estado. Em ambos os casos, podemos observar o efeito que essa mudanças provocam no aparato judicial. Como veremos adiante, as medidas sócio-educativas não garantem o desaparecimento puro e simples da idéia de punição, mas ela é transferida para outra esfera de ação; continua vindo pela mão dos juízes, mas de uma maneira que poderíamos classificar de criativa, se não fosse perversa.

Fica claro então porque o ECA é tão importante. Além de conhecer a legislação e seu contexto de criação, é preciso compreender seu valor simbólico, tendo em vista os atores em questão e, mais do que isso, compreender os conflitos operacionais que ele causa e explicita. Tratase de analisar o uso dessa legislação e o campo de relações que ela mobiliza.

Em 2005, o Estatuto da Criança e do Adolescente completou quinze anos e segue alvo de um debate controverso. Não há dúvida de que se trata de uma legislação moderna. Contudo, mesmo após esses anos, ele está longe de ser aplicado na sua plenitude.

As causas e conseqüências dessa lacuna entre o principio e sua efetivação são de natureza variada. Aqui, nos ocuparemos em tratar daquelas relacionadas aos itens que o próprio documento define como "da prática do ato infracional" e "do acesso à justiça", isto é, situações que envolvem o jovem em conflito com a lei e sua relação com o sistema de justiça. Mais especificamente, o que importa aqui é a apropriação do ECA, bem como sua aplicação por parte dos atores do sistema de justiça.

Remontar às audiências é uma oportunidade de ver o ECA em ação ou talvez melhor: assistir ao ECA em cena.

\section{AS "VARAS ESPECIAIS DA INFÂNCIA E DA JUVENTUDE"}

Ainda do lado de fora do prédio, mães, pais, irmãos e amigos aguardam, aglomerados na porta ou sentados na calçada, o horário das audiências que vieram acompanhar, ou pelo menos - quando não são autorizados a entrar no fórum - o resultado dessas audiências. 
Logo na entrada, há um detector de metais. Mediante a apresentação da minha "carteirinha" da universidade, tenho minha bolsa revistada e sou autorizada a subir. O que encontro no andar de cima é um espaço confuso e denso. De um lado, uma espécie de grande sala de espera, com cadeiras fixadas ao chão, dispostas como numa sala de cinema, ocupadas pelos parentes dos jovens que estão ali para serem julgados. Mais à frente estão outras salas, de onde não param de entrar e sair pessoas em busca de informações. A sala maior abriga a Procuradoria de Assistência Judiciária (PAJ), uma outra menor, quase sempre vazia, é a sala da Ordem dos Advogados do Brasil (OAB).

De maneira geral, a tensão que marca esse ambiente é diferente daquela que caracteriza o espaço institucional. O medo na sala de espera das VEIJ não era de uma rebelião ou de algum tipo de atitude violenta por parte dos jovens que aguardavam a audiência. A tensão estava muito mais ligada ao medo de ser internado ou voltar para a Febem; de ter seu filho, irmão ou parente internado. Soma-se a isso a sensação de não poder fazer nada a respeito, de, na maioria dos casos, depender totalmente da assistência judiciária gratuita e da sua pouca disponibilidade em função do número de casos que atende.

Seja pela disposição do espaço físico ou pela distância que a dinâmica do fórum guarda da vida cotidiana, a apreensão que se cria na espera deixa claro o quão intimidante é o protocolo da justiça.

A confusão que marca esse primeiro ambiente tem fim quando entramos no corredor que abriga as VEIJ. Esse corredor é separado por uma porta sempre fechada, controlada por um vigia. Nesse ambiente, o silêncio predomina. Não se ouvem as conversas que se ouviam do outro lado da porta, nem se vê a mesma circulação de pessoas. Além das VEIJ, "do outro lado da porta" está a sala onde os jovens acusados esperam pelas audiências.

Uma vez na sala de audiência, encontramos um cenário onde os personagens/atores se mantêm fixos caso a caso. Em volta de uma mesa sentam-se acusação, defesa, réu e juiz. A tarefa de acusação é desempenhada pela figura do promotor de justiça. Representantes do Ministério Público, os promotores são fiscais da lei que representam os interesses da sociedade (vale lembrar que a categoria "sociedade" inclui, pelo menos a princípio, os jovens em julgamento).

Em alguns casos, do mesmo lado da mesa estão as vítimas ou eventuais testemunhas. Do outro lado, está o adolescente acusado (réu) a quem o direito chama de parte interessada (embora ele não pareça ser a única).

Como veremos, no drama das audiências os jovens entram em cena apenas como coadjuvantes. A seu lado está o advogado de defesa e, na maioria dos casos, algum parente. Em função da baixa renda dos jovens e de suas famílias, o advogado de defesa é, na maioria das vezes, da Procuradoria de Assistência Judiciária do Estado de São Paulo. A PAJ exerce o papel da defensoria pública, ou seja, fornece advogado para a 
[15] Cintra et alli, op. cit., p. 293.

população que não tem condição de custear um advogado particular (também chamado de advogado constituído). No processo, sua função é mesma de um advogado particular: fazer a defesa do adolescente.

$\mathrm{Na}$ época da pesquisa, a PAJ contava com o trabalho de 12 procuradores, mais alguns estagiários, que respondiam por cerca de $85 \%$ a $90 \%$ da demanda de defesa no referido fórum. Apenas o restante dos casos era atendido por um advogado constituído. A assistência judiciária gratuita é prevista no ECA e na Constituição Federal. O grupo de procuradores da PAJ, nas VEIJ, é composto por pessoas jovens, comprometidas com uma "causa", que, diferentemente da maioria dos advogados constituídos, conhecem perfeitamente o ECA. Como veremos a seguir, têm uma postura clara em relação ao estatuto e à atuação dos juízes e promotores.

De frente para ambos os lados e num nível acima encontra-se a mesa do juiz. Logo a seu lado, está o escrivão, que registra toda a audiência numa ata a ser assinada ao final por todos os presentes. $O$ juiz é o que se chama de "sujeito imparcial do processo" já que "a qualidade de terceiro estranho ao conflito em causa é essencial à condição de juiz"15. Como sujeito imparcial, o juiz representa o interesse coletivo, orientado para a justa resolução do litígio. A magistratura é o conjunto de juízes que integram o Poder Judiciário. No caso dos juízes das VEIJ, eles já estão na magistratura há muito tempo, atuaram em outras cidades paulistas ou até de outras varas judiciais. Cada juiz tem seu "estilo" na condução das audiências. Grosso modo, mantém-se fiel a ele em todos os casos, sem atentar às diferenças entre um adolescente e outro, entre uma audiência e outra.

Uma vez apresentados os atores, vale a pena refletir sobre seu espaço de atuação. A melhor forma de fazê-lo é recorrer às cenas. Apresentamos aqui uma série de oito casos que reconstroem audiências acompanhadas em diferentes VEIJ. A escolha desses casos, entre outros observados, não foi aleatória; além de ilustrativos no que diz respeito à apresentação dos atores, da cena e da própria dinâmica das audiências, são especialmente emblemáticos, uma vez que expõem vários dos aspectos que queremos explorar neste ensaio.

As rápidas informações sobre o acusado que introduzem cada caso foram obtidas no início da audiência, durante a leitura que o juiz faz do processo. Por essa razão, variam em termos de precisão e extensão.

\section{CASO 1}

Dois meninos entram na sala. O primeiro, com 15 anos, está na quinta série, seus pais são separados, vive com a mãe. O segundo tem 13 anos, os pais também são separados, vive com o pai, mas visita a mãe toda semana. Ambos são acusados de assalto qualificado junto com um outro rapaz, maior de idade.

Juiz - Vocês participaram desse assalto? 
Menino 1-Meu amigo me convidou pra ir com ele, o de maior fez tudo.

Juiz - É a primeira vez que eles aparecem aqui...

Promotor-Eles alegam que o outro fez tudo, mas o que eles estavam fazendo

lá? Tem que dar internação.

Meninos começam a chorar.

Juiz - Pai, o que você garante?

Pai - Vamos ficar em cima.

Juiz - Eu vou dar uma LA (liberdade assistida).

Juiz se levanta e em voz alta ameaça os meninos e seus pais:

Juiz - Vocês se livraram dessa vez, mas da próxima não vai ter jeito. Pai, você tem que grudar igual carrapato. Mãe, você tem que ser igual a uma galinha, tem que por embaixo do braço. Entendido? Guardem seus filhos ou vocês vão perdê-los. Fica uma LA então.

Mãe - Jesus tava aqui.

Mãe pede pra fazer um auto que tinha prometido para Jesus, ajoelha e reza na sala de audiência, levanta e abraça o filho.

Todos se levantam, assinam papéis e saem da sala.

Juiz - O próximo já tá aí?

\section{CASO 2}

Menino de 17 anos, não estuda desde 1994, tem um irmão, mora com a mãe, o pai morreu. Trabalha como marceneiro.

Juiz - Seu processo diz que no dia 8 de janeiro de 1999 você entrou numbar armado e roubou um maço de cigarros, algum dinheiro e um relógio. É verdade isso?

Menino - É verdade.

Juiz - E por que vocêfez isso?

Menino - Mataram meu pai e eu quero mataro homem que matou meu pai. Os policias fizeram um acordo com ele porque ele é traficante. Queria matar e deixar um dinheiro para minha mãe.

Juiz - O caminho tem que ser o da justiça e não o da vingança. Procure um advogado e coloque esse homem na cadeia. Mesmo que não funcione, é a lei. Além disso, tem a justiça lá de cima.

Todas as partes lêem o que diz o relatório sobre o menino no momento da prisão, e do período em que esteve internado na Unidade da Febem Imigrantes, enquanto aguardava o julgamento. Juiz oferece para as partes:

Juiz - LA com obrigação de estudar, tá bom?

\section{CASO 3}

Menino de 17 anos, quinta série, trabalha como mecânico. Pais são separados, vive com a mãe, mas quem veio para a audiência foi a irmã. Foi julgado por receptação de peças de automóveis roubadas e por isso cumpria uma LA. 
Juiz - Aqui diz que você foi pego indo para um show com uma espingarda e estava cumprindo LA. É verdade?

Menino - $E$.

Promotor - O cara tá em LA e vai procurar confusão?

Juiz não ouve nem consulta advogado de acusação, nem de defesa.

Juiz - Eu vou dar mais um ano de LA, obrigação de trabalhar numa escola sete horas por semana e obrigação de estudar.

Juiz levanta, anda até o menino e em voz alta diz:

Juiz - Se você aparecer aqui de novo... você está proibido de sair de casa, você tá me entendendo?

Irmã começa a chorar.

Juiz - Olha pra sua irmã, o que você está vendo? Eu vejo uma irmã sofrendo, uma irmã envergonhada por ter um irmão nessa vida, é isso que você quer para a sua família? Você quer ver sua família sofrer, ter vergonha de você?

Menino começa a chorar também.

Juiz - Ficamos assim então.

Depois de assinar os papéis menino e irmã saem da sala.

Juiz - Vocês acham que eu me excedi?

\section{CASO 4}

Menino de 16 anos, não estuda, tem sete irmãos, mora com a avó, "avó é a mãe", lê a juíza. A mãe morreu, não conhece o pai.

Juíza descreve de maneira informal o acontecido:

Juiz - Você e um outro menino estavam andando num veículo roubado e foram parados pela polícia?

Menino $-\dot{E}$.

Juiz - Por que você estava num carro roubado?

Menino - Fui eu e o de maior, a gente não sabia que o carro era roubado.

Juiz - Você não sabia que o carro era roubado? Como então vocês conseguiram o carro?

Menino - ...

Juiz - Você sabe que roubar é crime?

Menino - Sei.

Juiz - Você mora com quem?

Menino - Com a minha mãe.

Juiz - (Fala para os dois advogados) Ele fala que não sabia que o carro era roubado, não dá né? Ele tem família, então entrega para a mãe (fala alto).

Mãe chora. Nesse mesmo momento juíza atende o celular, conversa um pouco e, ao desligar, olha para o menino e determina que ele fique em regime de semiliberdade, sem consultar nenhum dos dois advogados presentes.

\section{CASO 5}

Menino, 17 anos, mora em Santos com a mãe. 
Juiz - Eu te recomendo falar a verdade, pois se você falar a verdade vai ser melhor pra você. Se você mentir, você pode se prejudicar.

Juiz - Aqui diz que você roubou uma fita, picolés e um carrinho. Isso éverdade?

Menino - Sim senhor.

Juiz - Era um arrastão?

Menino - Sim senhor.

Juiz - Você já foi interno da Febem, não é verdade?

Menino - Peguei artigo 12 (tráfico de drogas).

Juiz - Você usa drogas?

Menino - Usei crack, mas parei.

Juiz - Desde quando você usa?

Menino - Usei dos 10 até os 16.

Juiz - Parou e tá numa boa? Você trabalha?

Menino - Sim.

Juiz - Bom, seu caso será julgado por Santos.

\section{CASO 6}

Menino, 15 anos, acompanhado do pai.

Juiz - Eu te aconselho a falar a verdade. Se vocêfalar a verdade você pode se beneficiar, se você mentir, você pode se prejudicar. Estou lendo aqui que você está sendo acusado pelo roubo de uma moto, isso aconteceu?

Menino - Não. Eu tenho uma moto igual a da menina que foi roubada, ela deve ter se confundido, mas eu não roubei a moto dela.

Juiz - Você estava em LA (liberdade assistida). Por quêe?

Menino - Porque eu roubei um cd player. Eu tô fazendo a coisa certa, acordo todo dia às 7 hda manhãparafazercurso, depoisvoupara escola. Oque osenhoracha?

Juiz - Quem tem que achar é você e pelo visto ainda não caiu sua ficha.

Nesse momento, a advogada da PAJ que defendia o menino na audiência diz ao juiz que vem acompanhando a liberdade assistida desse jovem, que ele tem feito os cursos propostos pelo agente da LA e que tem ido à escola regularmente. Ela pode garantir que ele está se esforçando. Finalmente, pede se o juiz não pode desinterná-lo naquele mesmo dia.

O juiz diz que não. Decide manter o menino interno na Unidade de Acolhimento Inicial, aguardando a próxima audiência.

\section{CASO 7}

Menino, 16 anos, veio acompanhado da mãe. Advogada constituída.

Juiz - Eu estou lendo aqui que você tentou furtar um carro e depois atirou em duas vítimas. Isso de fato ocorreu?

Menino - Ocorreu, mas eu só atirei porque eles tentaram me segurar e me bateram, foi aí que eu atirei.

Juiz - Ah, você acha que eles foram injustos com você? 
Menino - Não.

Juiz - Por que não?

Menino - Porque eu tava furtando o carro deles.

Juiz - A arma era sua?

Menino - Era.

Juiz - Você já terminou uma LA. O que eles te ensinaram na LA?

Menino - Eles me ensinaram tudo de bom, mas eu tava precisando do dinheiro porque bati o carro do meu colega.

Mãe começa a chorar e advogada de defesa pede ao juiz que pergunte ao menino se ele tinha consciência do que estava fazendo.

Juiz - Isso não é um tribunal do júri, quem vai julgar sou eu, a doutora não precisa fazer esse tipo de pergunta.

Juiz - Você vai ser internado e quando sair na rua de novo, não se meta em encrenca, não é esse tipo de comportamento que uma pessoa de bem deve ter.

Menino - Quanto tempo eu vou ficar internado?

Juiz - O Estatuto da Criança e do Adolescente prevê que a medida de internação seja reavaliada a cada seis meses. O período máximo de internação é de três anos.

Menino - Eu vou ser internado?

Juiz - Vai.

\section{CASO 8}

Dois meninos. O primeiro, de 16 anos, vem acompanhado do pai e da mãe. O outro, também de 16, está acompanhado só da mãe.

Juiz - Estou lendo aqui que vocês roubaram 16 reais de um casal que andava na rua. Isso é verdade?

Menino $1-E ́$ verdade. A gente tava bêbado e queria dinheiro pra ir no fliperama.

Pai - Se o senhor me dá licença, a gente dá mesada pra ele, ele tem tudo o que precisa, foi uma besteira isso o que eles fizeram, uma bobagem.

Juiz - Quem é o dono da sua liberdade? Cada um é o dono da própria liberdade. Hoje em dia nãofaz diferença se vocêé rico ou pobre, veja, por exemplo, o caso do juiz Lalau. Eu sou livre porque sou honesto.

Juiz - Vocês estavam na UAI (Unidade de Atendimento Inicial). O que essa experiência trouxe pra vocês?

Menino 1 - Esses quatro dias na Febem foram muito bons pra eu refletir.

Juiz - Vocês usam drogas?

Menino 2 - Eu usava maconha, mas parei de fumar porque minha mãe ficava triste.

Juiz - Espero que vocês tenham aprendido a lição, vocês não têm aparência alguma de serem violentos, deve ter sido besteira típica de adolescentes, mas não façam mais isso.

Meninos são liberados e vão embora com os respectivos pais. 
Antes de partirmos para análise, é necessário que sejam feitas duas ressalvas. A primeira diz respeito à particularidade das VEIJ onde foi feita a pesquisa: vários informantes classificaram-nas de casos particulares, seja pela "dureza" do Ministério Público, seja pela maneira peculiar como se dá o andamento dos processos legais. A segunda ressalva refere-se aos juízes. Além dos valores em jogo, a atuação do juiz no transcorrer das audiências pode ser descrita como indissociável de aspectos da sua personalidade. Alguns falam alto, outros gritam, alguns se levantam da mesa, outros mantêm o mesmo tom de voz durante toda a audiência. Alguns são mais "secos", outros têm jargões que repetem em toda audiência, independente do caso que se apresenta. Enfim, ao longo da pesquisa encontrei juízes diferentes e personalidades diferentes. Tais particularidades não puderam ser contempladas neste trabalho, tivemos que deixá-las de lado pra privilegiar as recorrências ${ }^{16}$.

Grosso modo, podemos descrever as audiências observadas da seguinte maneira: o caso é apresentado, o jovem é questionado quanto à veracidade das acusações que lhe são feitas, sendo a resposta, na maioria das vezes, afirmativa. Uma vez admitido o ato infracional por parte do acusado, o juiz determina a medida sócio-educativa que o adolescente vai receber. Teoricamente, acusação e defesa poderiam apresentar argumentos contra ou em favor do acusado, além de reivindicar uma medida mais leve ou mais dura. Na prática, no entanto, a apuração da culpabilidade em si parece uma mera formalidade. A solução para o conflito apresentado na audiência é resultado da decisão quase que exclusiva do juiz.

$\mathrm{Na}$ verdade, essa dinâmica não se fazia completamente clara na observação das primeiras audiências, especialmente porque se tratava do início da pesquisa. Fui aprendê-la de fato somente após ouvir a explicação que um juiz dava a um advogado constituído durante uma audiência. $\mathrm{O}$ adolescente representado pelo advogado era acusado de ter cometido um seqüestro relâmpago e de ter ameaçado a vítima com uma arma de fogo. O juiz determinou que o adolescente fosse internado na Febem, afinal tinha cometido um ato infracional grave. $\mathrm{O}$ advogado então pediu a palavra e tentou defender seu cliente, afirmando que ele nunca tinha feito nada parecido e que por isso mereceria uma medida mais leve. Antes mesmo que o advogado pudesse terminar seu argumento, o juiz o interrompeu para explicar:

Imagino que essa seja a primeira vez que o doutorvem aqui. Aqui as coisas são um pouco diferentes, o doutor não precisa defender seu cliente dessa forma, aqui nós sempre buscamos um acordo. Se o doutornão quiserfazerparte desse acordo, pode até vir a prejudicar seu cliente.

A explicação era perfeita. De fato, era assim que as audiências eram conduzidas. No entanto, o que o juiz chamava de "acordo", era, na verdade, sua supremacia na tomada de decisão.
[16] Falo em recorrências, pois julgo significativo o número de audiências que acompanhei. Ao longo dos quatro meses em que pesquisei no Fórum do Brás, pude assistir a uma média de 80 audiências. 
[17] Ver Adorno, Sérgio. Discriminação racial e justiça criminal em São Paulo. Novos Estudos Cebrap, São Paulo, n.43, p.45-63, nov. 1995, e Schritzmeyer, Ana Lúcia Pastore. Controlando o poder de matar: uma leitura antropológica do tribunal do júri - ritual lúdico e teatralizado. Tese de Doutorado apresentada à FFLCH-USP. São Paulo, 2001.

[18] Cintra, op. cit., p. 292

[19] Gregori, Maria Filomena. Meninos nas ruas: a experiência da viração. Tese de doutoramento apresentada à FFLCH-USP, São Paulo, 1997, p. 248.
Esse "papel principal" ocupado pelo juiz no processo de decisão não é exclusividade das VEIJ. Outros estudos apontam o lugar primordial e determinante do magistrado ${ }^{17}$.

No caso das VEIJ, esse tipo de conduta não só se repete, mas é potencializada, praticamente anulando a participação de qualquer outro ator no desenvolvimento da audiência que não seja a do próprio juiz. Isso, no entanto, não significa que as outras partes estejam menos envolvidas com o processo, mas o poder de atuação naquele espaço específico é desigual - aquele é o espaço do juiz.

Nos termos jurídicos, o processo é um "instrumento para a resolução imparcial de conflitos que se verificam na vida social" ${ }^{18}$. A idéia de "aplicação da lei" como desfecho desses processos oculta os interesses, as disputas e as pressões que estão em jogo. Na verdade, o que temos nas audiências é uma disputa política sobre a questão, mais do que uma contenda por esse ou aquele caso. O confronto que resulta na aplicação de uma medida sócio-educativa coloca de um lado promotores e juízes e de outro a procuradoria.

Gregori aponta que, no que se refere às audiências, "o problema maior parece ser a incapacidade dos adolescentes e dos seus acompanhantes - familiares e educadores - de fazer frente à manipulação do ritual pelos protagonistas - juiz, promotor e advogado - , que transformam sistematicamente o menino não em 'sujeito', mas em objeto de intervenções ${ }^{19}$."

Diagnosticar esse lugar de objeto de disputa e de intervenção reservado para os jovens é de fato importante uma vez que essa transfiguração em "objeto" se opõe à idéia do adolescente como sujeito de direitos, grande mudança conquistada pelo Estatuto da Criança e do Adolescente. No entanto, é preciso fazer uma distinção entre as diferentes motivações envolvidas nessa disputa, bem como verificar de que maneira essas motivações se traduzem em estilos diferentes de intervenção.

\section{HORA DA LIÇÃo}

Um bom ponto de partida para essa reflexão seria a informalidade com a qual são conduzidas as audiências. Além de saltar ao olhar não familiarizado, essa informalidade opõe, de saída, juízes e procuradores. O que estamos chamando de informalidade inclui atender ao celular no meio da audiência, falar alto com a mãe do adolescente, tecer comentários com o escrivão, a breve duração (normalmente, as audiências duram cerca de 20 minutos), mas também a pouca preocupação com as garantias processuais. O conjunto dessas garantias foi uma das conquistas do ECA. $O$ estatuto prevê a igualdade do adolescente na relação processual (cap. III, art. 111), isto é, além do direito a ser representado por um advogado, o jovem pode "confrontar-se com vítimas e testemunhas e produzir todas as provas necessárias à sua 
defesa". Contudo, a presença de testemunhas nas audiências era fato raríssimo (quando apareciam eram sempre de acusação) e, sobretudo, parecia não haver tempo, espaço ou interesse na produção de provas ou nas eventuais testemunhas de defesa.

Nesse sentido, o maior objetivo das audiências parece ser o de dar uma "lição". Essa talvez seja a palavra-chave para compreendê-las. Tudo o que aconteceu até então parece ter importância menor; é a "lição" dada pelo juiz o grande saldo da audiência. Para isso, ele repassa a trajetória de vida do jovem, cita dados biográficos como a morte do pai, "a batalha da mãe para mantê-lo no bom caminho", passagens anteriores pela Febem, o futuro que o espera, recorre à nobreza que reside em falar a verdade, altera o tom de voz e enfatiza o gestual, numa tentativa de imprimir dramaticidade ao momento. Em diversas ocasiões, o juiz acaba fazendo parentes e meninos chorarem, "pela vergonha de ter um filho criminoso". Pode-se dizer que, como numa peça de teatro, quanto mais elementos em cena, melhor é a "qualidade de encenação" 20 e, conseqüentemente, mais real torna-se a história. O processo parece catártico: todos choram, joga-se com as emoções, cria-se um cenário onde só o bem pode triunfar.

A atuação do juiz não só ofusca a participação dos advogados de defesa e de acusação, mas também estabelece condutas informais que se tornam um padrão na resolução dos casos.

A informalidade nas cortes juvenis é um fenômeno apontado por procuradores, promotores e juízes. Contudo, é percebida de maneira diferente por cada uma dessa partes. Os juízes, por exemplo, não associam informalidade ao tema das garantias processuais. Nas palavras de um juiz, o que tratamos como informalidade na condução das audiências, na verdade tem um outro sentido:

Não é bem a informalidade, os critérios são diferentes, é ficar chamando a atenção do jovem, é recompor uma série de padrões pra ele, você me viu falar de verdade, quem é o dono da sua liberdade, é isso que você quer da sua vida? Pra nós é uma função obrigatória, porque aqui nós estamos recompondo, tentando refazer condutas, limites posturas, diferente da esfera penal. Na esfera penal, o sujeito praticou um crime ele vai receber uma pena, não importa o que ocorra, ou o que deixe de acontecer, porque para cada crime, uma pena. Aqui não, aqui nós vamos aplicar uma medida. Se então é ressocialização, então nós temos uma função pedagógica, diferentemente da esfera penal. Por isso que aqui nós somos um pouquinho professores, orientadores, uma série de outras coisas diferentes de um juiz criminal $^{21}$.

Para a PAJ, no entanto, a informalidade está associada à rapidez com que cada audiência é conduzida e conseqüentemente é o fator responsável pela supressão das garantias processuais. De acordo com um procurador:
[20] Geertz, Clifford. A interpretação das culturas. Rio de Janeiro, Editora LTC, 1989.
[21] As entrevistas com juízes e procuradores apresentadas nesse trabalho foram todas realizadas em junho de 2001. Na época, não discuti com os entrevistados se poderia identificá-los. Logo, ainda que corra o risco de enfraquecer o argumento do trabalho, em nome de uma certa "etiqueta de pesquisa", optei por não fazê-lo sem a devida autorização. Pelo mesmo motivo, achei preferível não editar os depoimentos. 
"Se você analisar o respeito que os juizes têm às garantias processuais, de defesa dos adultos que respondem processo criminal e está sujeita a uma pena, ela é muito maior do que o respeito que os juizes têm das garantias do adolescente. Parte dessa idéia equivocada que a medida de internação não teria uma carga punitiva, que eu particularmente entendo que ela tenha, embora o objetivo dela seja sócio-educativo, é inegável que ela tem uma carga de constrangimento. Eles não percebendo isso, acabam sendo muito menos rigorosos na apuração dos fatos [e] na observância das formalidades legais do que deveriam ser".

Retomando os casos apresentados, conseguimos entender por que os juízes se considerariam um pouco professores, ou orientadores. Em se tratando de lição, não há melhor caracterização. Não importa o caso que se apresente, a conduta é sempre a mesma. Somos levados a pensar que, para os juízes, a suspeita de estar em conflito com a lei por si só já estabelece uma identidade sob a qual são classificados todos os jovens que passam pelas VEIJ. Culpados ou não, reincidentes ou primários, os jovens estão ali e só por isso merecem desconfiança, um susto e, acima de tudo, uma lição.

Vimos, por exemplo, que em um dos casos apresentados a infração não seria julgada pela vara em São Paulo (isso é sabido pelo juiz desde o início da audiência). No entanto, mesmo assim, o jovem é levado a dar detalhes do acontecimento e do seu eventual envolvimento com as drogas. As drogas, aliás, são assunto obrigatório em qualquer audiência. Mesmo que o ato infracional pelo qual o jovem é acusado não tenha nenhuma ligação com o consumo de drogas, o juiz sempre os questiona, bem como retoma o assunto ao final da audiência, na "hora da lição". Ao fazer isso, os juízes expõem ainda mais os jovens. Eles estão lá para ser julgados por um ato infracional específico, mas acabam sendo julgados moralmente - mesmo quando têm sua inocência comprovada - por outros aspectos da sua vida. O que está em questão não é só o ato, mas sua conduta como um todo. No limite, é esse o desvio que se tenta corrigir.

A idéia de falar a verdade é um ponto importante na relação entre juiz e réu. Mesmo quando não há necessidade, os jovens acabam revelando fatos que podem thes prejudicar no andamento do processo como, por exemplo, confessar infrações cometidas anteriormente. Tais revelações podem servir de indicativo para o juiz de que aquele jovem já está no "caminho do crime", o que pode acarretar numa medida sócioeducativa mais dura para o adolescente.

A pressão colocada sobre a idéia de verdade não está só no ambiente das VEIj; ela perpassa todo o universo judiciário, incluindo o período de internação provisória.

De acordo com um procurador,

existe uma cultura arraigada entre os adolescentes no sentido de que têm que confessar, ao contrário do que acontece na justiça de maiores é difícil explicar 
por quê; existe uma pressão por parte do juiz, você assistiu à audiência da $1^{a}$ Vara onde o juiz fala "se você confessar eu te ajudo" e só essa fala do juiz vale muito mais do que o advogado conversando horas com o cliente dele, agora desde que o menino entra na Unidade de Internação da Febem existe essa perspectiva um pouco moralizante "olha você tem sempre que dizer a verdade, assim você vai se beneficiar" e a própria cultura institucional tem um peso muito grande, ou seja, o menino que vem pra audiência já passou algum tempo observando essa cultura de confirmação mesmo.

Alguns juízes, no entanto, enxergam o falar a verdade "como um processo de auto-conscientização". Todavia, esse processo, da maneira como é apresentado, traz necessariamente a figura do juiz como mediador. O adolescente participa falando "a verdade" e o juiz entra com a auto-conscientização, uma vez que é ele quem interpreta a verdade e tem o poder de utilizá-la da maneira que bem entender.

Como contrapartida à informalidade, assistimos à cristalização de certas atitudes que acabam por constituir uma maneira pessoal, particular e não menos estigmatizante de interpretação e aplicação do ECA.

O problema não é a lição em si - isso, em algum grau, parece fazer parte do ofício da magistratura -, mas o lugar privilegiado que ela ocupa na condução do processo. "Dar uma lição" é um gesto obviamente associado à punição, mas parece, na verdade, uma espécie de compensação pelo fato de o réu ter cometido um ato infracional e, ainda assim, livrar-se da internação.

Normalmente, leva-se uma lição quando se está recebendo uma medida sócio-educativa que não implique a supressão da liberdade. De fato, podemos dizer que, para os juízes, apenas a internação se apresenta como um mecanismo efetivo de punição; as outras medidas não têm esse caráter, podem dar a impressão ao jovem de que ele não será punido pela infração. Por isso, toda medida que não seja a internação acaba vindo acompanhada de uma lição.

Voltemos à fala do procurador. Além da lição, o aspecto formal da condução de uma audiência é também um problema. A maneira como são conduzidos os processos acaba por pressionar a procuradoria. Esta trabalha basicamente com duas possibilidades: o réu fala a verdade e continua internado na unidade de atendimento inicial, aguardando a continuidade do processo; ou assume um ato infracional (em alguns casos que não cometeu) e consegue a desinternação no mesmo dia, saindo das VEIJ com uma liberdade assistida. Tal impasse explicaria a suposta recomendação que os jovens recebem para admitir o ato infracional na frente do juiz. Os procuradores afirmam que apenas expõem as opções:

se você admitir a infração hoje, você já sai daqui com uma liberdade assistida, se você negar, você vai ficar internado mais 30 dias chegando lá nessa $2^{a}$ audiência, vindo os policiais, o juiz vai te dar a mesma $L A$ que você poderia estar recendo hoje. 


\section{CRITÉrios}

Primeiro, nós analisamos a ocorrência do ato infracional, provada a autoria, aí passa-se à análise do auto para que a medida seja aplicada. A gente leva em conta alguns requisitos: a gravidade do ato infracional, o envolvimento do adolescente no mundo infracional, se ele já está inserido nesse mundo infracional ou se ele está de passagem. Se o ato que ocorreu foi um ato momentâneo ou se ele já está nesse sistema infracional há algum tempo. A gente leva em conta o respaldo familiar, se a família tem condições de tirar o jovem dessa criminalidade ou se efetivamente o Estado precisa tomar as vezes da família pra ajudar a família a reformular a postura, caráter, limites, uma série de coisas. Então, nós levamos em conta vários aspectos, sempre nos baseando também em matéria subjetiva que é a conceituação que um jovem tem a respeito das coisas. Muitas vezes, você chamar a atenção verbalmente de alguém, é muito mais sério para aquele ser humano do que você pegar e prender a pessoa ....

A fala reproduzida acima diz respeito aos critérios utilizados para determinação de uma medida sócio-educativa. Sabemos que os juízes não utilizam o ECA de forma homogênea, tampouco objetiva. As variáveis que condicionam a medida a ser aplicada estão, de fato, ligadas ao tipo de infração cometida, tal como recomenda o estatuto. Como vimos na declaração acima, a presença na audiência dos pais do adolescente conta como ponto positivo; o vínculo com a escola e a relação série/idade são levados em consideração. Esses critérios podem ser interpretados como uma preocupação do Poder Judiciário com a estrutura familiar do jovem, a disposição e condição da família em se responsabilizar pelo acompanhamento e educação do filho. Entretanto, a determinação de uma medida ou de outra, principalmente em se tratando das infrações mais leves, é também fruto de uma interpretação, ou de um diagnóstico imediato da situação: o que o nosso "nativo" chamou de "conceituação que um jovem tem das coisas". Essa conceituação pode ser interpretada como "sentimento de culpa": o juiz procura, ao longo da audiência, verificar o arrependimento do jovem, o impacto do acontecido sobre ele. Com efeito, o garoto mostrar arrependimento, chorar e ter vergonha, também conta pontos, podendo amenizar a medida a ser aplicada. Nos casos em que as medidas são efetivamente brandas, esse parece ser visto como um desfecho de sucesso, sinal de que a lição foi bem assimilada. Logo, o objetivo é menos a punição e mais o teatro bem feito e a lição bem dada. Na ótica dos juízes, essa dinâmica parece mais eficaz do que as medidas previstas na lei.

\section{SENTIMENTO DE JUSTIÇA}

Geertz alerta que, para falar apropriadamente sobre as bases culturais do direito, é preciso levar em consideração o "sentimento de 
justiça" 22 local. O antropólogo não se refere apenas ao contexto, mas ao que significa "fazer justiça" nesse contexto. No caso tratado aqui, é possível traçar um caminho - do mais amplo ao mais particular que leve a uma definição mais precisa do que seria esse sentimento de justiça. Começamos pelo modelo ocidental de direito e de justiça e a relação que o Brasil estabelece com as leis em geral ${ }^{23}$; prosseguimos com a distribuição desigual da renda no país, o que já seria suficiente para questionar se esse meio ambiente social permitiria a ação igualitária do direito. Além disso, temos o sentimento de insegurança advindo da violência das metrópoles, as polêmicas que envolvem o Estatuto da Criança e do Adolescente, as rebeliões na Febem e, finalmente, a figura do "menor infrator" como protagonista de ações criminosas. A combinação desses elementos forma o que poderíamos chamar de sentimento de justiça em relação aos jovens em conflito com a lei. Tal sentimento tem o poder de influenciar desde a postura do Ministério Público até as decisões dos juízes; se transveste de um sentimento de impunidade, cobrança social e clamor por justiça.

As dificuldades de efetivação do Estatuto da Criança e do Adolescente - tanto da sua aplicação por parte do Judiciário, quanto na sua concretização enquanto instrumento reabilitador - provocam uma percepção equivocada sobre o seu papel na reeducação e reinserção social dos jovens em conflito com a lei. Hoje, o ECA é associado à inimputabilidade. A medida sócio-educativa idealizada para não ser uma punição penal é vista como punição alguma. Com efeito, essa demanda punitiva se configura em valores sociais que penetram o ambiente das audiências e, por conseguinte, o universo dos juízes. Disputando espaço com a tecnicidade da aplicação da lei, criam um rito discriminatório que atende a estereótipos e preconceitos.

A atitude dos juízes, no entanto, não pode ser interpretada apenas na chave da punição. Vimos que o aparato público de efetivação das medidas prevista no ECA é insuficiente e ineficaz. A PAJ atende mais casos do que a sua estrutura permite, os postos de liberdade assistida, em sua maioria, não conseguem levar a cabo os projetos educativos e a Febem, não é, em nenhum sentido, uma instituição de educação e reabilitação. A percepção dessa realidade parece guiar a ação dos juízes que apelam para o recurso da "lição" como forma de compensar essa incapacidade, tentando condensar o processo de educação e ressocialização nos possíveis efeitos do seu discurso. É claro que tal postura dá margem a atitudes que não são exatamente a "interpretação da lei", mas a manifestação dos valores pessoais de cada juiz e o direcionamento político do próprio Ministério Público, traduzidas numa conduta responsável por constrangimentos que podem ser tão intransigentes quanto a aplicação de uma medida sócio-educativa severa.

PAULA MirAgLIAé mestreem Antropologia pelo departamento deAntropologia Social da Universidade de São Paulo e doutoranda no mesmo departamento.
[22] Geertz, Cliford. O saber local. $3^{\mathrm{a}}$ ed., Petrópolis, Editora Vozes, 2000.

[23] Roberto DaMatta mostra como, no Brasil, o sistema legal tem significado diverso para os diferentes setores da sociedade. $\mathrm{O}$ autor observa uma vertente individualizante presente no aparato legal "aos indivíduos, à lei, às pessoas, tudo". DaMatta, Roberto. Carnavais, malandros e heróis. Rio de Janeiro, Editora Rocco, 1997.

Recebido para publicação em 28 de fevereiro de 2005.

\section{NOVOSESTUDOS}

CEBRAP

$\mathrm{n}^{\mathrm{o}} 72$, julho 2005

pp. $79-98$ 
ENSAIO

99 


\section{ENSAIO}

